\title{
Pharmacognostic Specifications, RP-HPLC Analysis of Chlorogenic Acid Content and Antioxidant Activity of Morus alba Linn. Leaves in Thailand
}

\author{
Phimkun Aiyarakanchanakun ${ }^{1}$, Chanida Palanuvej ${ }^{1}$, Nijsiri Ruangrungsi ${ }^{1,2}$, Anuchit Phanumartwiwath ${ }^{1, *}$
}

Phimkun Aiyarakanchanakun', Chanida Palanuvej', Nijsiri Ruangrungsi ${ }^{1,2}$,

Anuchit Phanumartwiwath ${ }^{1, *}$

${ }^{1}$ College of Public Health Sciences, Chulalongkorn University, Bangkok, THAILAND.

${ }^{2}$ Department of Pharmacognosy, College of

Pharmacy, Rangsit University, Pathum Thani,

THAILAND.

\section{Correspondence}

Anuchit Phanumartwiwath, Ph.D.

College of Public Health Sciences,

Chulalongkorn University, Bangkok 10330,

THAILAND.

Phone no: +662-218-8043

E-mail: anuchit.p@chula.ac.th

History

- Submission Date: 07-06-2021;

- Review completed: 03-07-2021.

- Accepted Date: 09-07-2021.

DOI : 10.5530/pj.2021.13.152

Article Available online

http://www.phcogj.com/v13/i5

Copyright

(C) 2021 Phcogj.Com. This is an openaccess article distributed under the terms of the Creative Commons Attribution 4.0 International license.

\begin{abstract}
Background: Morus alba Linn. leaves have been widely used as herbal medicine with therapeutics and contain chlorogenic acid as a bioactive phenolic compound. Objective: The present study aimed to conduct the pharmacognostic specifications of $M$. alba leaves and the method validation for quantification of chlorogenic acid content. Materials and Methods: Macroscopic- and microscopic characteristics, physicochemical parameters combined with quantification of chlorogenic acid in $M$. alba leaves collected from 15 sources throughout Thailand and their antioxidant activity were reported in this study. Results: The physicochemical parameters of $M$. alba leaves were determined by indicating water content $(7.97$ $\pm 0.35 \%)$, loss on drying $(4.55 \pm 0.21 \%)$, total ash (14.38 $\pm 0.25 \%)$, acid-insoluble ash $(6.21 \pm 0.37 \%)$, water-extractive value $(16.14 \pm 0.50 \%)$ and ethanol-extractive value $(8.61 \pm 0.39 \%)$. In addition, the chlorogenic acid contents in $M$. alba leaves were found to be $0.4159 \pm 0.1958 \mathrm{~g} / 100 \mathrm{~g}$ dry weight. The ethanolic leaf extracts exhibited their antioxidant activity with half-maximal inhibitory concentration $\left(\mathrm{IC}_{50}\right)$ values (326.09-467.55 $\mathrm{gg} / \mathrm{mL})$. Conclusion: This study showed the establishment of pharmacognostic study of $M$. alba leaves and validation of the reversed-phase high-performance liquid chromatography (RPHPLC) quantitative analysis of their chlorogenic acid contents, which are applicable to be a reference for quality control and standardization of $M$. alba leaves.

Key words: Antioxidant activity, Chlorogenic acid, Morus alba, Pharmacognostic specification, Quality control.
\end{abstract}

\section{INTRODUCTION}

Morus alba Linn., a deciduous tree in the family Moraceae, is commonly known as a white mulberry. M. alba leaves are usually cultivated to use as feed of silkworms and produced as a food for livestock. Additionally, M. alba leaves have been widely used as herbal medicine in many countries such as China, Thailand, Korea, India, etc., and its leaves are famous to make an oriental herbal tea. ${ }^{1,2}$ Fresh and dried M. alba leaves are medicinally used to treat various common illnesses such as cough, asthma, bronchitis, fever, sore throat, headache, dizziness and vertigo, beriberi and constipation. ${ }^{3}$ The pharmacological studies of $M$. alba leaf extracts and their bioactive compounds have shown a variety of biological activities such as antioxidant activity $^{4}$, antimicrobial activity ${ }^{5}$, antidiabetic activity $^{6-8}$, anti-obesity activity ${ }^{9}$, neuroprotective activity $^{10}$, hepatoprotective activity ${ }^{11}$, antimelanogenesis activity ${ }^{12}$ and cytotoxic activity. ${ }^{13}$ Many potential phenolic compounds are isolated from leaf extracts of $M$. alba such as quercetin, rutin, apigenin, chlorogenic acid and quercetin3-O-glycoside (Figure 1).${ }^{14}$ A chlorogenic acid, a natural phenolic compound containing an ester bond of caffeic acid and quinic acid, is one of main bioactive ingredients found in $M$. alba leaves. The chlorogenic acid shows several biological activities such as antioxidant, cardioprotective, antibacterial, hepatoprotective, anti-inflammatory, antipyretic, anti-obesity, neuroprotective, antiviral, antimicrobial, anti-hypertension activities as well as central nervous system (CNS) stimulator. ${ }^{15,16}$

Although herbal medicine has been widely used; however, the pharmacognostic study is still required to determine the quality and purity of herbal materials to ensure substances with therapeutic effects by using various parameters like morphological-, microscopic-, physical-, chemical examinations, etc. ${ }^{17}$ However, the study of pharmacognostic specification and quantification of the chlorogenic acid content of $M$. alba leaves have been never established. Thus, this study focused on the investigation of pharmacognostic parameters to authenticate $M$. alba leaves as well as quantitative analysis of chlorogenic acid content. Additionally, phytochemical analysis, total phenolic content, total flavonoid content, and antioxidant activity of the ethanolic leaf extracts of $M$. alba were evaluated.

\section{MATERIALS AND METHODS}

\section{Plant materials}

M. alba leaves were collected from 15 different sources throughout Thailand and authenticated by Associate Professor Nijsiri Ruangrugsi as an expert in the field of Pharmaceutical Botany and Pharmacognosy. The specimens were deposited at the College of Public Health Sciences, Chulalongkorn University in Bangkok, Thailand. Fresh leaf samples were cleaned by removing foreign matters, subsequently dried by a hot air oven and pulverized into finely ground powders before using.

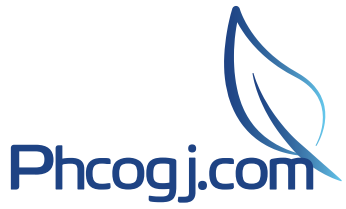

Cite this article: Aiyarakanchanakun $\mathrm{P}$, Palanuvej $\mathrm{C}$, Ruangrundsi N, Phanumartwiwath A. Pharmacognostic Specifications, RP-HPLC Analysis of Chlorogenic Acid Content and Antioxidant Activity of Morus alba Linn. Leaves in Thailand. Pharmacogn J. 2021;13(5): 1186-1194. 


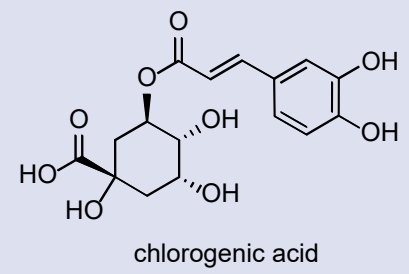<smiles>O=c1cc(-c2ccc(O)cc2)oc2cc(O)cc(O)c12</smiles><smiles>O=c1c(O)c(-c2ccccc2)oc2cc(O)cc(O)c12</smiles>
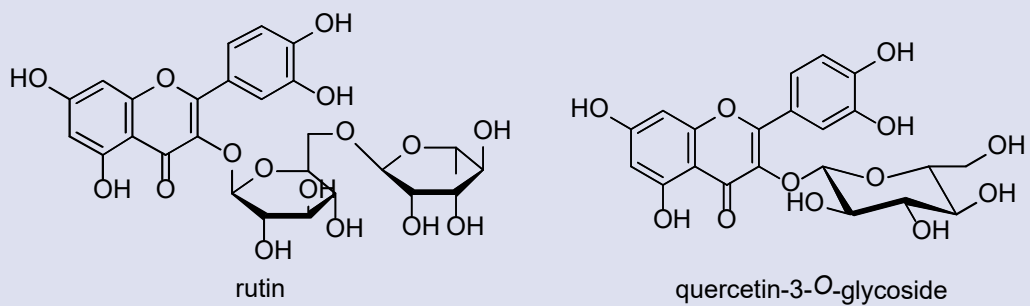

quercetin-3-O-glycoside

Figure 1: Structures of bioactive phenolic compounds isolated from $M$. alba leaf extracts.

\section{Determination of pharmacognostic specifications}

The pharmacognostic specifications involving macroscopic and microscopic evaluations, determination of the water content, ethanol- and water-soluble extractive values, loss on drying, total ash, acid-insoluble ash and thin layer chromatography (TLC) fingerprint were followed using World Health Organization (WHO) guideline, $2011 .^{17}$

\section{Macroscopic and microscopic evaluations}

Macroscopic examination is a process used for identification of medicinal plant materials. The morphological description of $M$. alba leaves was determined by size, shape, color, surface characteristics, texture, and other visible inspections.

Microscopic evaluation of $M$. alba. leaves with transverse sections and powder analysis were examined under a microscope to determine their anatomical and histological characteristics. Leaf measurement using mature leaves from different 3 sources was investigated for leaf constant numbers. The chlorophyll pigment was removed by soaking in a mixture of haiter ${ }^{ø}(6 \%$ sodium hypochlorite) and water $(1: 1, \mathrm{v} / \mathrm{v})$ for 1-2 d. After that, the prepared leaves, which were soaked in a mixture of chloral hydrate:water $(4: 1, \mathrm{w} / \mathrm{v})$, were heated on a waterbath at $60^{\circ} \mathrm{C}$ for $2 \mathrm{~d}$. The average of leaf constant numbers, using three selected sources of collected leaves, was carried out with a total of 90 fields (30 fields for each source). For powder analysis, dried powders of $M$. alba leaves were mixed with a solution of chloral hydrate and further examined under the microscope with magnification of $5 \times, 10 \times$, $20 \times$ and $40 \times$ objective lens.

\section{Stomatal number and stomatal index}

The stomata cell was counted in the area of one square millimeter $\left(\mathrm{mm}^{2}\right)$ of the lower epidermis of the leaf. The cells on the four edges were only counted on top and left sides. The percentage proportion of stomatal index was calculated using the following Equation 1:

Stomatal index $=\frac{\mathrm{S}}{\mathrm{B}+\mathrm{S}} \times 100$

$\mathrm{E}=$ the number of epidermal cells in the same unit area

$\mathrm{S}=$ the number of stomata per one square millimeter of lower epidermis

\section{Trichome number and trichome index}

The trichome cell was counted on the area of one square millimeter $\left(\mathrm{mm}^{2}\right)$ of the upper epidermis of the leaf. The cells on the four edges were only counted on top and left sides. The percentage proportion of stomatal index was calculated using the following Equation 2:

Trichome $=\frac{\mathrm{T}}{\mathrm{E}+\mathrm{T}} \times 100$

$\mathrm{E}=$ the number of epidermal cells in the same unit area

$\mathrm{T}=$ the number of trichome or cicatrix per one square millimeter of upper epidermis

\section{Physicochemical determination}

Determination of the water content of leaf powders $(50.0 \mathrm{~g})$ was conducted by azeotropic distillation method using water-saturated toluene $(300 \mathrm{~mL})$. Determination of extractive matters was conducted by maceration of dried and ground leaf powders $(5.0 \mathrm{~g})$ with $95 \%$ ethanol or water $(70 \mathrm{~mL})$ under conditions of shaking for $6 \mathrm{hr}$. and standing for $18 \mathrm{hr}$. The marc was then filtered and washed. The filtrate was adjusted to $100 \mathrm{~mL}$ with ethanol or water, after that the filtrate $(20 \mathrm{~mL})$ was transferred to a pre-weighed small beaker which was dried on a water bath and subsequently dried at $105^{\circ} \mathrm{C}$ for $6 \mathrm{hr}$. before weighing. Determination of loss on drying, total ash and acid-insoluble ash contents was continuously investigated. The loss on drying was conducted by drying a crucible containing leaf powders $(3.0 \mathrm{~g})$ at $105^{\circ} \mathrm{C}$ for $6 \mathrm{hr}$., and a percentage of the loss of weight was calculated. Then, the crucible, which contained the solid matters from loss on drying, was incinerated at $500^{\circ} \mathrm{C}$ for $5 \mathrm{hr}$., until it became white to yield the carbonless total ash. The content of the total ash was calculated in a percentage. After that, the ash was boiled with $25 \mathrm{~mL}$ of $\sim 2 \mathrm{M} \mathrm{HCl}$ (70 g/L) for $5 \mathrm{~min}$, filtered through the ashless filter paper and further incinerated at $500^{\circ} \mathrm{C}$ for $5 \mathrm{hr}$., yielding the percentage of the acidinsoluble ash. All aforementioned experiments of leaf samples were done in triplicate.

For determination of TLC fingerprint, the ethanolic extract was spotted on a TLC silica gel 60 GF254 plate as a stationary phase and further developed in a TLC chamber pre-saturated with a mixture of ethyl acetate: methanol: water: formic acid (16.8:1.2:1.2:0.4, v/v/v/v) as a mobile phase. The developed plate was air-dried and examined under visible light, ultraviolet (UV) light at wavelengths of 254 and $366 \mathrm{~nm}$ and detected by a sulfuric acid reagent.

\section{Preparation of ethanol leaf extracts of $M$. alba}

Dried powders of $M$. alba leaves (5.0 g) from 15 sources throughout Thailand were exhaustively extracted with $95 \%$ ethanol $(300 \mathrm{~mL})$ using 
a Soxhlet apparatus. The ethanolic extract was filtered and evaporated under reduced pressure in a rotary evaporator. The percentage yield of each extract was calculated by comparing with its dry weight. The ethanolic extracts were stored at $-20^{\circ} \mathrm{C}$ for further manipulations.

\section{Phytochemical screening tests}

Phytochemical screening of the ethanolic leaf extract of M. alba was studied to analyze a group of secondary metabolites. The phytochemical screening tests involved analysis of phenolic compounds (Ferric chloride test), analysis of flavonoids (Shinoda and Alkaline tests), analysis of alkaloids (Dragendorff's, Wagner's and Hager's tests), analysis of steroids and triterpenes (Salkowski and Liebermann Burchard tests) and analysis of saponins (Foam test). ${ }^{18,19}$ The measurement was carried out by comparing with an original color of the leaf extract sample.

\section{Quantitative analysis of chlorogenic acid contents by RP-HPLC}

A standard solution of chlorogenic acid in methanol (conc. $10 \mathrm{mg} / \mathrm{mL}$ ) was prepared in a volumetric flask. The solution was filtered through a $0.45 \mu \mathrm{m}$ polytetrafluoroethylene (PTFE) membrane syringe filter. The stock solution was diluted to obtain a series of six working standard solutions with concentrations of $0.005,0.01,0.02,0.03,0.04$ and 0.05 $\mathrm{mg} / \mathrm{mL}$, respectively.

Each stock solution of ethanolic extracts in methanol (conc. $10 \mathrm{mg} /$ $\mathrm{mL}$ ) was diluted to obtain an appropriate concentration for further RPHPLC analysis. Each prepared solution was filtered through a $0.45 \mu \mathrm{m}$ PTFE membrane syringe filter.

RP-HPLC analysis of the chlorogenic acid content in crude ethanolic leaf extracts was monitored by Shimadzu HPLC LL-20A system (Shimadzu, Japan) consisting of a controller (CMB-20A), an autosampler (SIL-20A), an online degassing unit (DGU-20A3), a solvent delivery unit (LC-20A) and a photo-diode array detector (SPDM20A). The chromatographic separation was performed with a C18 column $(4.6 \times 250 \mathrm{~mm})$ and coupled with C18 guard column $(4.6 \times 10$ $\mathrm{mm})$ as a stationary phase. The prepared samples of crude ethanolic extracts were injected and analyzed by eluting with $0.2 \%$ phosphoric acid in water (solvent $\mathrm{A}$ ) and methanol (solvent B) as a mobile phase. Both solvents were filtered through $0.45 \mu \mathrm{m}$ PTFE membrane filter (methanol) and $0.45 \mu \mathrm{m}$ nylon membrane filters $(0.2 \%$ phosphoric acid in water), and subsequently degassed by the ultrasonic bath. The elution program was set at $45 \%$ methanol in an isocratic mode for $50 \mathrm{~min}$ at a flow rate of $0.5 \mathrm{~mL} / \mathrm{min}$. The column temperature was maintained at $30^{\circ} \mathrm{C}$ and the injection volume of a standard and/or samples was 10 $\mu \mathrm{L}$. The chromatographic profile was monitored at a wavelength of 330 $\mathrm{nm}$. The measurement was carried out in triplicate.

\section{Method validation}

According to the ICH guideline (Q2R1), the analytical method for chlorogenic acid contents in M. alba leaves was validated for linearity, accuracy, precision, specificity, limit of detection (LOD), limit of quantitation (LOQ) and robustness. ${ }^{20}$ The measurement was carried out in triplicate.

\section{Determination of the total phenolic content}

The total phenolic content of crude ethanolic leaf extracts of $M$. alba was determined by the Folin-Ciocalteu assay. ${ }^{21}$ In brief, each stock solution of a gallic acid $(100 \mu \mathrm{g} / \mathrm{mL})$ as a standard and samples $(100 \mu \mathrm{g} / \mathrm{mL})$ was prepared in methanol. All stock solutions were diluted by twofold serial dilution to obtain a series of solutions with concentrations of 50.0, 25.0, 12.5, 6.25, 3.12 and $1.56 \mu \mathrm{g} / \mathrm{mL}$. Both prepared standard and sample solutions $(50 \mu \mathrm{L})$ were mixed with $10 \%$
Folin-Ciocalteu reagent $(50 \mu \mathrm{L})$ in a 96-well microplate which was incubated in dark for $20 \mathrm{~min}$. A solution of $7.5 \%$ sodium carbonate $(50 \mu \mathrm{L})$ was added and further incubated at room temperature in dark for $20 \mathrm{~min}$. Absorbance was measured at a wavelength of $765 \mathrm{~nm}$ using UV-visible spectrophotometer, and determination of the total phenolic content was performed using gallic acid as a standard calibration curve. The result of the total phenolic content was expressed as mg gallic acid equivalents (GAE) /g extract. The measurement was carried out in triplicate.

\section{Determination of the total flavonoid content}

The total flavonoid content of crude ethanolic leaf extracts of $M$. alba was determined by aluminium chloride colorimetric assay. ${ }^{21}$ In brief, each stock solution of a quercetin $(100 \mu \mathrm{g} / \mathrm{mL})$ as a standard and samples $(100 \mu \mathrm{g} / \mathrm{mL})$ was prepared in methanol. All stock solutions were diluted by twofold serial dilution to obtain a series of solutions with concentrations of 50.0, 25.0, 12.5, 6.25, 3.12 and $1.56 \mu \mathrm{g} / \mathrm{mL}$. Both prepared standard and sample solutions $(50 \mu \mathrm{L})$ were mixed with $10 \%$ aluminium chloride solution $(10 \mu \mathrm{L})$ in a 96-well microplate, and then added ethanol $(150 \mu \mathrm{L})$ and $1 \mathrm{M}$ sodium acetate solution $(10$ $\mu \mathrm{L})$ and further incubated at room temperature in dark for $40 \mathrm{~min}$. Absorbance was measured at a wavelength of $415 \mathrm{~nm}$ using UV-visible spectrophotometer, and determination of the total flavonoid content was performed using quercetin as a standard calibration curve. The result of the total flavonoid content was expressed as mg quercetin equivalents $(\mathrm{QE}) / \mathrm{g}$ extract. The measurement was carried out in triplicate.

\section{Evaluation of antioxidant activity by DPPH assay}

1,1-Diphenyl-2-picryl-hydrazyl (DPPH) radical scavenging activity of crude ethanolic leaf extracts of M. alba was determined. ${ }^{21}$ In brief, each stock solution of an ascorbic acid $(100 \mu \mathrm{g} / \mathrm{mL})$ as a positive control, chlorogenic acid $(100 \mu \mathrm{g} / \mathrm{mL})$ and samples $(100 \mu \mathrm{g} / \mathrm{mL})$ was prepared in methanol. All stock solutions were diluted by twofold serial dilution to obtain a series of solutions with concentrations of 50.0,25.0, $12.5,6.25,3.12$ and $1.56 \mu \mathrm{g} / \mathrm{mL}$. Both prepared standard and sample solutions $(20 \mu \mathrm{L})$ were mixed with a solution of DPPH in methanol $(180 \mu \mathrm{L})$ in a 96 -well microplate, and further incubated at $37^{\circ} \mathrm{C}$ in dark for $30 \mathrm{~min}$. Absorbance was measured at a wavelength of $517 \mathrm{~nm}$ using UV-visible spectrophotometer. The percentage of radical scavenging activity (RSA) was calculated by following Equation 3:

$\% \mathrm{RSA}=\frac{A b s_{\text {control }}-A b s_{\text {sample }}}{A b s_{\text {control }}} \times 100$

$\mathrm{Abs}_{\text {control }}=$ the absorbance of a negative control

$\mathrm{Abs}_{\text {sample }}=$ the absorbance of a crude extract solution or a positive control

The results were expressed as a half-maximal inhibitory concentration $\left(\mathrm{IC}_{50}\right)$ value which was determined by a plot of the crude extract sample concentrations versus percentages of radical scavenging activity. The measurement was carried out in triplicate and represented as $\mathrm{IC}_{50}$ value \pm standard deviation (SD).

\section{Statistical analysis}

The data were represented as mean $\pm \mathrm{SD}$ of the results obtained from the experiments in triplicate. The physicochemical parameters were calculated using grand mean and pooled SD. Determination of significant levels was tested using one-way analysis of variance (ANOVA) with the SPSS software (version 22; SPSS Inc.; Chicago, IL, USA). Statistically significance was considered at $p<0.05$. 


\section{RESULTS}

\section{Macroscopic and microscopic evaluations}

M. alba leaves collected from 15 sources throughout Thailand were identified by macroscopic and microscopic evaluations. The fresh mature leaves of $M$. alba were green on both upper and lower epidermis sides, heart-shaped, thin, $10-15 \mathrm{~cm}$ wide, and $20-25 \mathrm{~cm}$ long. The color of dried leaf powders was green to dark green. The results of microscopic evaluation of the midrib cross-section showed the presence of epidermis cells and non-glandular trichome at the outer epidermis surface, and chlorenchyma cells and vascular bundles (xylem and phloem) at the inner layer (Figure 2).

The leaf constant values of $M$. alba leaves including epidermal cell number, epidermal cell area, stomatal number, stomatal index, trichome number, trichome index, and palisade ratio were shown in Table 1. Powder analysis of $M$. alba leaves under the microscope showed the presence of trichome, epidermal cell, parenchyma, anomocytic stoma and non-glandular trichome (Figure 3).

\section{Physicochemical determination}

The contents of physicochemical parameters of $M$. alba leaves including water content, water-extractive value, ethanol-extractive value, loss on drying, total ash and acid insoluble ash were shown in Table 2. The water content and loss on drying were averaged at $7.97 \pm$ $0.35 \%$ and $4.55 \pm 0.21 \%$ of dry weight, respectively. The total ash and acid-insoluble ash contents were averaged at $14.38 \pm 0.25 \%$ and 6.21 $\pm 0.37 \%$ of dry weight, respectively. The water-extractive and ethanolextractive values were averaged at $16.14 \pm 0.50 \%$ and $8.61 \pm 0.39 \%$ of dry weight, respectively.

For the TLC fingerprint, the ethanolic leaf extract of M. alba was observed under visible light, UV at the wavelength of 254 and 366 $\mathrm{nm}$ and subsequently sprayed with $10 \%$ sulfuric acid in ethanol for the detection of phenolic compounds (Figure 4). The results of the TLC fingerprint under visible light showed approximately 6 bands, but their observation under UV radiation at 254 and $366 \mathrm{~nm}$ showed approximately 8-9 bands. Additionally, the TLC fingerprint detected with $10 \%$ sulfuric acid in ethanol showed approximately 10 bands.

\section{Quantitative analysis of chlorogenic acid contents by RP-HPLC}

All percentage yields of crude ethanolic extracts of $M$. alba leaves from 15 sources in Thailand were found to be averaged at $26.54 \pm 3.98 \%$, and their chlorogenic acid contents were found to be averaged at 0.4159 $\pm 0.1958 \mathrm{~g} / 100 \mathrm{~g}$ dry weight (Table 3 ). The quantitative analysis of chlorogenic acid contents of all ethanolic leaf extracts of $M$. alba were determined by RP-HPLC analysis together with use of a standard curve of chlorogenic acid (Figures 5 and 6).

The method validation parameters for the RP-HPLC quantitative analysis of chlorogenic acid contents were evaluated and shown in Table 4 . The analytical method for chlorogenic acid contents in $M$. alba leaves was validated to be accurate (94.84\%) and specific (1.00) for identification of peak purity index. Additionally, the method

Table 1: Microscopic evaluation of leaf constant numbers (mean \pm SD) of $M$. alba leaves throughout Thailand.

\begin{tabular}{|c|c|c|c|c|}
\hline \multirow{2}{*}{ Leaf constant values } & \multicolumn{2}{|c|}{ Upper epidermis } & \multicolumn{2}{|c|}{ Lower epidermis } \\
\hline & Min - max & Mean \pm SD & Min - max & Mean \pm SD \\
\hline $\begin{array}{l}\text { Epidermal cell number } \\
\left(\text { per } \mathrm{mm}^{2}\right)\end{array}$ & $1008-1540$ & $1216.53 \pm 141.65$ & $284-588$ & $438.89 \pm 81.88$ \\
\hline $\begin{array}{l}\text { Epidermal cell area } \\
\left(\mu \mathrm{m}^{2}\right)\end{array}$ & $649.35-992.06$ & $832.68 \pm 93.16$ & $1700.68-3521.13$ & $2361.30 \pm 456.31$ \\
\hline $\begin{array}{l}\text { Stomatal number } \\
\left(\text { per } \mathrm{mm}^{2}\right)\end{array}$ & - & - & $140-280$ & $193.56 \pm 33.63$ \\
\hline $\begin{array}{l}\text { Stomatal index } \\
\left(\text { per } \mathrm{mm}^{2}\right)\end{array}$ & - & - & $22.35-37.57$ & $30.80 \pm 3.82$ \\
\hline Trichome number & $12-28$ & $15.87 \pm 4.00$ & - & - \\
\hline Trichome index & $0.80-2.19$ & $1.29 \pm 0.30$ & - & - \\
\hline Palisade ratio & $13.25-17.75$ & $15.10 \pm 1.17$ & - & - \\
\hline
\end{tabular}

- = not found.

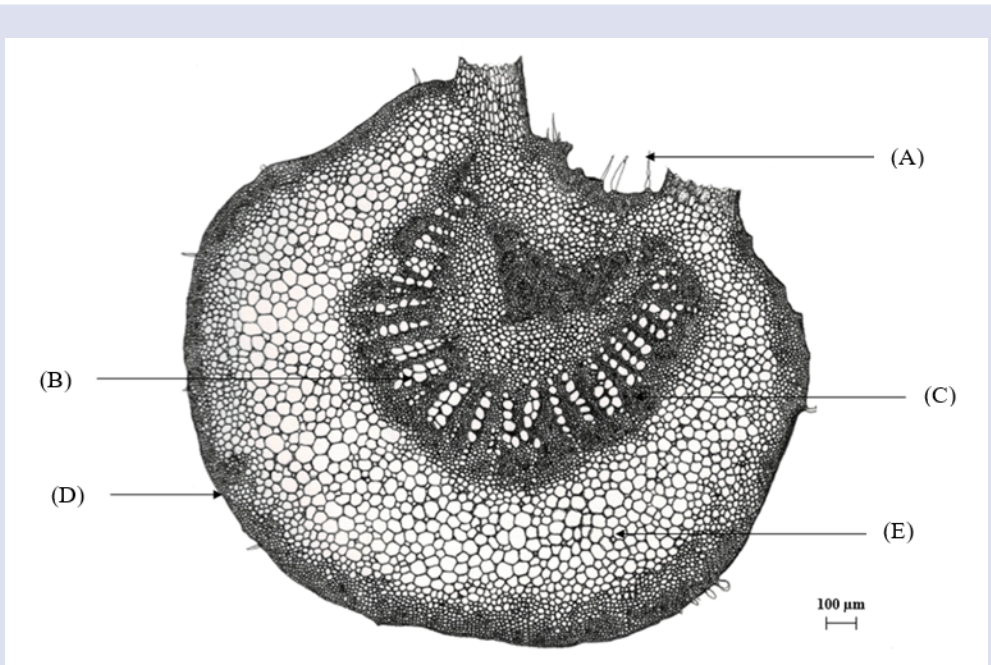

Figure 2: Midrib cross section of $M$. alba leaves: (A) non-granular trichome; (B) xylem; (C) phloem; (D) epidermis; (E) chlorenchyma. 


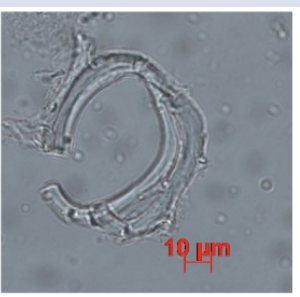

(A)

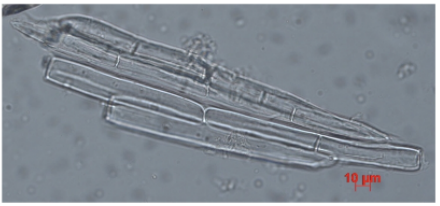

(C)

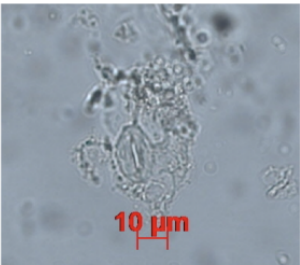

(D)

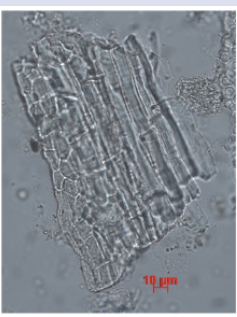

(B)

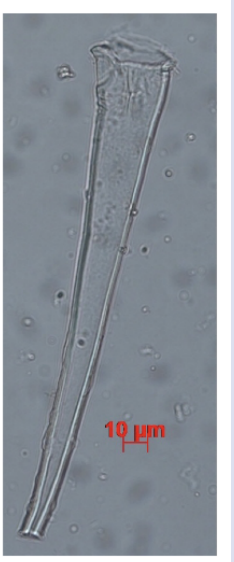

(E)
Figure 3: Powder analysis of $M$. alba leaves: (A) trichome; (B) epidermal cell; (C) parenchyma cell; (D) anomocytic stomata; (E) non-glandular trichome.

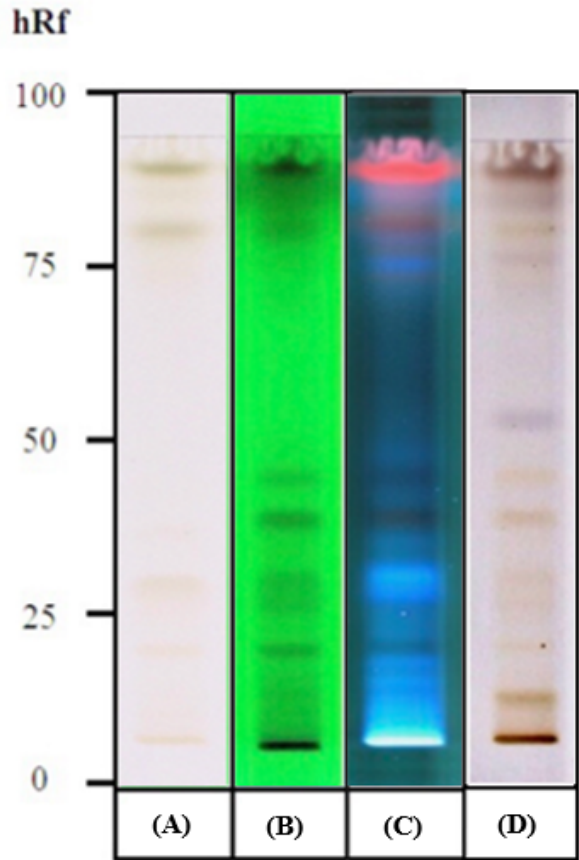

Figure 4: TLC fingerprint of ethanolic leaf extract of $M$. alba: (A) under visible light; (B) under UV (254 nm); (C) under UV (366 nm); (D) sprayed with $10 \%$ sulfuric acid in methanol.
Table 2: Physicochemical parameters (grand mean \pm pooled SD) of $\boldsymbol{M}$. alba leaves from 15 sources throughout Thailand.

\begin{tabular}{lc} 
Parameter & $\begin{array}{c}\text { Content (\% of dry weight) } \\
\text { (Grand mean } \pm \text { pooled SD) }\end{array}$ \\
\hline Water content & $7.97 \pm 0.35$ \\
Loss on drying & $4.55 \pm 0.21$ \\
Total ash & $14.38 \pm 0.25$ \\
Acid-insoluble ash & $6.21 \pm 0.37$ \\
Water-extractive value & $16.14 \pm 0.50$ \\
Ethanol-extractive value & $8.61 \pm 0.39$
\end{tabular}

Table 3: Percentage yields by Soxhlet extraction and chlorogenic acid contents by RP-HPLC analysis (mean \pm SD; $n=3$ ) of $M$. alba leaves from 15 sources throughout Thailand.

\begin{tabular}{lccc} 
Source & $\begin{array}{c}\text { Weight of } \\
\text { extractive } \\
\text { matter } \\
\text { (g/5.00 g } \\
\text { dried leaf) }\end{array}$ & $\begin{array}{c}\text { The percentage } \\
\text { yield by Soxhlet } \\
\text { extraction }(\%)\end{array}$ & $\begin{array}{c}\text { Chlorogenic acid } \\
\text { content } \\
\text { (g/100 g dry } \\
\text { weight) }\end{array}$ \\
\hline Ratchaburi & 1.63 & 32.48 & $0.8756 \pm 0.0011^{\mathrm{n}}$ \\
Yasothon & 1.18 & 23.23 & $0.6095 \pm 0.0016^{\mathrm{m}}$ \\
Prachinburi & 1.32 & 26.34 & $0.5785 \pm 0.0014^{1}$ \\
Nakhon Pathom & 1.56 & 31.07 & $0.5601 \pm 0.0001^{\mathrm{k}}$ \\
Phetchabun & 1.49 & 29.88 & $0.5032 \pm 0.0053^{\mathrm{j}}$ \\
Phitsanulok & 0.95 & 18.93 & $0.4615 \pm 0.0002^{\mathrm{i}}$ \\
Mahasarakham & 1.20 & 23.88 & $0.4583 \pm 0.0029^{\mathrm{i}}$ \\
Buriram & 1.52 & 30.22 & $0.4475 \pm 0.0015^{\mathrm{h}}$ \\
Suphanburi & 1.15 & 22.76 & $0.3561 \pm 0.0006^{\mathrm{g}}$ \\
Nakhon Ratchasima & 1.41 & 28.21 & $0.3272 \pm 0.0005^{\mathrm{f}}$ \\
Khon Kaen & 1.54 & 30.59 & $0.3122 \pm 0.0007^{\mathrm{e}}$ \\
Roiet & 1.31 & 26.29 & $0.2766 \pm 0.0005^{\mathrm{d}}$ \\
Rayong & 1.16 & 23.08 & $0.2070 \pm 0.0006^{\mathrm{c}}$ \\
Chanthaburi & 1.13 & 22.61 & $0.1946 \pm 0.0001^{\mathrm{b}}$ \\
Nakhon Phanom & 1.43 & 28.49 & $0.0703 \pm 0.0054^{\mathrm{a}}$ \\
Mean \pm SD & $1.33 \pm 0.20$ & $26.54 \pm 3.98$ & $0.4159 \pm 0.1958$ \\
\hline
\end{tabular}

Mean values with different superscript letters in the same column denote significant $(p<0.05)$ different between groups.

Table 4: The method validation of RP-HPLC quantitative analysis of chlorogenic acid contents in M. alba leaves.

\begin{tabular}{ll}
\hline Parameter & Validation \\
\hline Linearity & $\mathrm{y}=55074 \mathrm{x}-135166$ \\
& $\left(\mathrm{R}^{2}=0.9981\right)$ \\
Accuracy (\%recovery) & 94.84 \\
Limit of detection $(\mathrm{mg} / \mathrm{mL})$ & 0.0028 \\
Limit of quantitation $(\mathrm{mg} / \mathrm{mL})$ & 0.0086 \\
Repeatability (\%RSD: $5,20,40 \mu \mathrm{g} / \mathrm{mL})$ & $1.10,0.24,0.14$ \\
Intermediate precision $(\% \mathrm{RSD}: 5,20,40 \mu \mathrm{g} / \mathrm{mL})$ & $0.73,1.06,3.01$ \\
Robustness (\%RSD) & 0.17 \\
Specificity (Peak purity index) & 1.00
\end{tabular}

RSD = relative standard deviation .

validation showed both LOD $(0.0028 \mathrm{mg} / \mathrm{mL})$ and LOQ $(0.0086 \mathrm{mg} /$ $\mathrm{mL})$. Intermediate precision measured at concentrations of 5, 20 and $40 \mu \mathrm{g} / \mathrm{mL}$ for the method validation was $0.73 \%, 1.06 \%$ and $3.01 \%$ respectively, but its repeatability with same concentrations was $1.10 \%$, $0.24 \%$ and $0.14 \%$ respectively.

\section{Phytochemical screening tests}

The phytochemical screening of the selected crude ethanolic leaf extract of $M$. alba (source from Mahasarakham) showed the detection of 
Table 5: Phytochemical screening of the ethanolic leaf extract of $M$. alba (source from Mahasarakham).

$\begin{array}{lcc}\text { Phytochemical test } & \text { Ethanolic } \\ \text { extract* }\end{array}$

$*_{+}=$present; - = absent.

Table 6: The total phenolic content (mean $\pm S D ; \mathbf{n}=3$ ), the total flavonoid content (mean \pm SD; $\mathbf{n = 3}$ ) and DPPH radical scavenging activity (mean IC ${ }_{50}$ value $\pm S D ; n=3$ ) of ethanolic extracts of $M$. alba leaves from 3 representative sources.

\begin{tabular}{lccc} 
Ethanolic extract & $\begin{array}{c}\text { Total phenolic content } \\
(\mathrm{mg} \mathrm{GAE} / \mathrm{g} \text { extract })\end{array}$ & $\begin{array}{c}\text { Total flavonoid content } \\
(\mathrm{mg} \mathrm{QE} / \mathrm{g} \text { extract })\end{array}$ & $\begin{array}{c}\mathrm{IC}_{50} \text { value } \\
(\mu \mathrm{g} / \mathrm{mL})\end{array}$ \\
\hline Ratchaburi & $67.70 \pm 2.93^{\mathrm{c}}$ & $67.20 \pm 3.41^{\mathrm{c}}$ & $388.22 \pm 15.69^{\mathrm{b}}$ \\
Khon Kaen & $60.54 \pm 2.59^{\mathrm{b}}$ & $58.51 \pm 2.24^{\mathrm{b}}$ & $326.09 \pm 38.38^{\mathrm{a}}$ \\
Mahasarakham & $49.79 \pm 2.77^{\mathrm{a}}$ & $49.70 \pm 4.50^{\mathrm{a}}$ & $467.55 \pm 13.50^{\mathrm{c}}$ \\
Chlorogenic acid $^{\mathrm{c}}$ & $\mathrm{ND}$ & $\mathrm{ND}$ & $24.53 \pm 0.30$ \\
${\text { Ascorbic } \text { acid }^{*}}^{\mathrm{N}}$ & $\mathrm{ND}$ & $\mathrm{ND}$ & $16.89 \pm 0.42$
\end{tabular}

*Positive control; ND = not determined; mean values with different superscript letters in the same column denote significant $(p<0.05)$ different between groups.
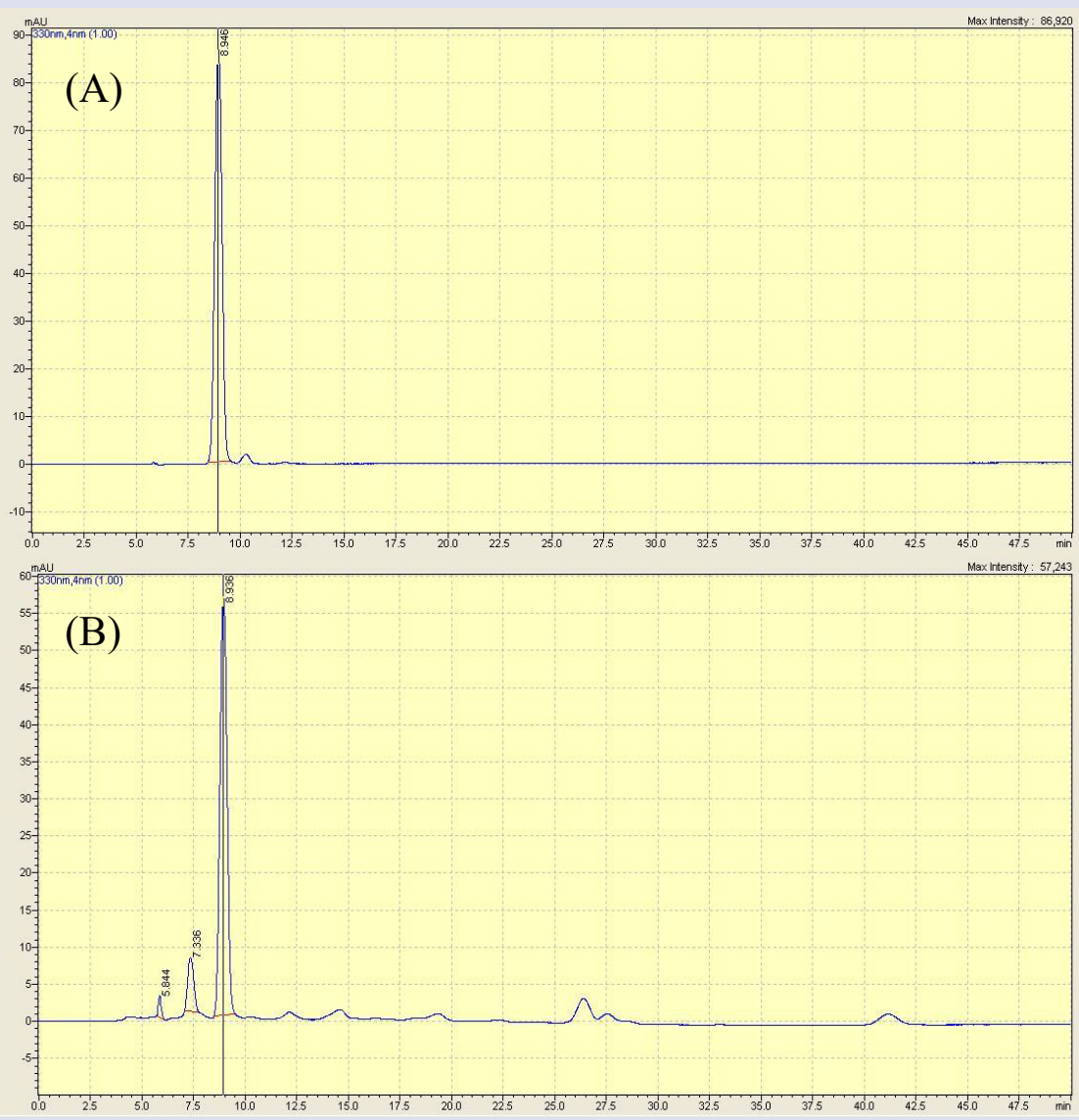

Figure 5: RP-HPLC quantitative analysis of chlorogenic acid content in the ethanolic leaf extract of M. alba: (A) RP-HPLC profile of chlorogenic acid (standard); (B) RP-HPLC profile of the ethanolic leaf extract of M. alba (source from Khon Kean). 


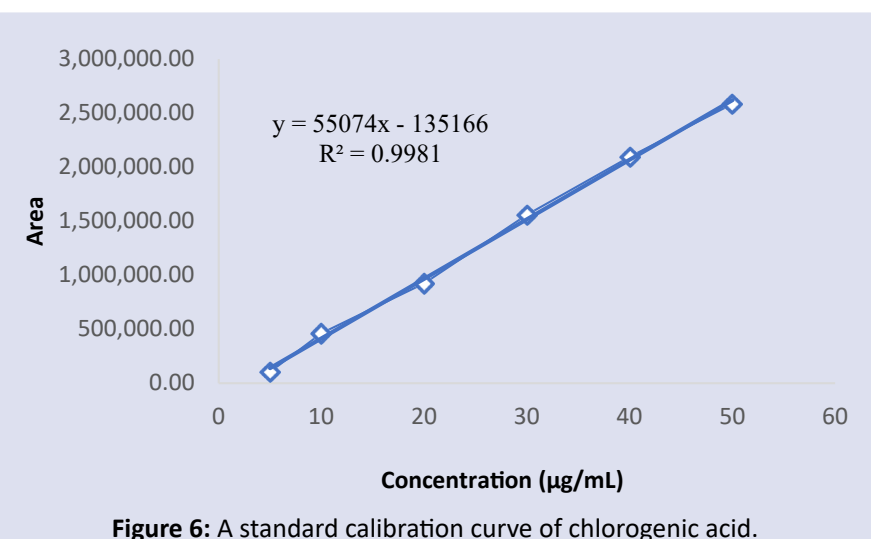

various bioactive compounds including phenolics, flavonoids, steroids, and triterpenes (Table 5).

\section{Total phenolic content, total flavonoid content, and antioxidant activity}

Both total phenolic and total flavonoid contents of ethanolic leaf extracts of $M$. alba from 3 representative sources were found to be 49.79-67.70 mg GAE/g extract and 49.70-67.20 mg QE/g extract, respectively (Table 6). Additionally, the antioxidant activity of three ethanolic leaf extracts were evaluated by comparing with chlorogenic acid as a main phenolic compound and ascorbic acid as a positive control (Table 6). Results showed the relatively moderate antioxidant activity with $\mathrm{IC}_{50}$ values ranging from 326.09 to $467.55 \mu \mathrm{g} / \mathrm{mL}$.

\section{DISCUSSION}

Pharmacognostic specifications involving macroscopic and microscopic characteristics of medicinal plants are important to determine the quality and purity of crude drugs. Microscopic and microscopic evaluations of $M$. alba leaves were described. The stoma of M. alba leaves was found to be an anomocytic type which had a same size and shape guard cell arrangement as the rest of the epidermis cells, and the non-glandular trichome was round, oval, and short tip. The findings correlated with the previous study of $M$. alba leaves cultivars from Poland. ${ }^{22}$

Examination of the physicochemical parameters is required for the quality control of the herbal materials. According to the measurement of the water content in the plant material using the azeotropic distillation method, it showed that the water content of dried leaf powders should not be higher than $7.97 \pm 0.35 \%$. The higher water content may cause the microbial growth (e.g., bacteria and fungi). In a comparison between water and ethanol extractions, the result showed that the water-extractive value was higher than the ethanol-extractive value which indicated an enormous amount of highly water-soluble polar compounds in M. alba leaves. Both water-extractive and ethanolextractive values should not be less than $16.14 \pm 0.50 \%$ and $8.61 \pm 0.39 \%$, respectively. Determination of the total ash was evaluated for inorganic substances in plant materials after incineration such as $\mathrm{Na}, \mathrm{Ca}, \mathrm{K}$, etc., This parameter showing the indication of adulterants, contaminants or substitutes found in medicinal plants should not be higher than 14.38 $\pm 0.25 \%$. Determination of acid-insoluble ash was a measurement of amounts of inorganic matters that they were not solubilized in a hydrochloric acid solution. The acid-insoluble ash in a form of silica or silicate were found in $M$. alba leaves, and this value should not be higher than $6.21 \pm 0.37 \%$. The TLC fingerprint of herbal materials shows characteristic appearance of organic compounds found in the crude extract. For the TLC fingerprint of the ethanolic leaf extract of $M$. $a l b a$, it showed some similar bands which were detected under UV at 254 and $366 \mathrm{~nm}$. According to the enrichment of phenolics in M. alba leaves, the TLC fingerprint of the ethanolic leaf extract was monitored by oxidation reactions of phenolics with a sulfuric acid to visualize bands of their oxidized forms. The investigation of physicochemical parameters and TLC fingerprints could be indicated as good markers for controlling the quality of $M$. alba leaves.

The RP-HPLC is a reliable, accurate and precise technique which is widely used for qualitative and quantitative analysis of bioactive compounds derived from the crude extract. RP-HPLC profiles showed the detection of an individual peak of chlorogenic acid found in the ethanolic leaf extract at a retention time $\left(\mathrm{R}_{\mathrm{t}}\right)$ of 8.936 min which was similar to a peak of the standard $\left(R_{t}=8.946 \mathrm{~min}\right)$ (Figure 5). Determination of the chlorogenic acid contents of ethanolic leaf extracts of $M$. alba showed that the highest content of chlorogenic acid was found in the ethanolic extract of $M$. alba leaves from Ratchaburi $(0.8756 \pm 0.0011 \mathrm{~g} / 100 \mathrm{~g}$ dry weight); on the other hand, the lowest chlorogenic acid content of M. alba leaves was from Nakhon Phanom $(0.0703 \pm 0.0054 \mathrm{~g} / 100 \mathrm{~g}$ dry weight). The findings showed that a variation of chlorogenic acids content of $M$. alba leaves possibly depended on geographical areas and environmental growth conditions.

Evaluation of the total phenolic and total flavonoid contents with antioxidant activity of $M$. alba leaf extracts were described. According to the determination of total phenolic and total flavonoid contents, the ethanolic leaf extract from Ratchaburi had both the highest total phenolic content $(67.70 \pm 2.93 \mathrm{mg} \mathrm{GAE} / \mathrm{g}$ extract $)$ and the highest total flavonoid content $(67.20 \pm 3.41 \mathrm{mg} \mathrm{QE} / \mathrm{g}$ extract). For the DPPH radical scavenging activity, the results showed that the ethanolic leaf extract from Khon Kaen had the highest antioxidant ability with an $\mathrm{IC}_{50}$ value of $326.09 \pm 38.38 \mu \mathrm{g} / \mathrm{mL}$; however, both chlorogenic acid and ascorbic acid as natural antioxidant compounds showed better DPPH radical scavenging activity with $\mathrm{IC}_{50}$ values of $24.53 \pm 0.30$ and $16.89 \pm 0.42 \mu \mathrm{g} / \mathrm{mL}$, respectively). This study showed that the total phenolic and total flavonoid contents of these ethanolic leaf extracts and their $\mathrm{IC}_{50}$ values for DPPH radicals were significantly higher than the ethanolic extracts of $M$. alba leaves collected in Hebei, China. ${ }^{23}$ The phytochemical analysis of the crude ethanolic leaf extract showed the presence of phenolics and flavonoids as major bioactive compounds which correlated to the determination of both total phenolic and total flavonoid contents. Both steroids and triterpenes were also detected; however, alkaloids and saponins were undetectable in the crude ethanolic extract of $M$. alba leaves. This study showed that the phytochemical analysis results, for example, triterpenes, flavonoids, phenolics and alkaloids, were in accordance with the previous study. ${ }^{5}$ The findings showed that ethanolic leaf extracts containing phenolics as major ingredients, i.e., chlorogenic acid, were active against DPPH radicals.

\section{CONCLUSION}

The pharmacognostic specifications of $M$. alba leaves from 15 sources throughout Thailand were established by investigating macroscopic and microscopic characteristics, physicochemical contents and RPHPLC analysis of chlorogenic acid contents in M. alba leaves. This study could be used as a reference for quality and purity of $M$. alba leaves which is applicable to the quality control and standardization.

\section{ACKNOWLEDGEMENT}

This work is supported by the Development of New Faculty Staff, Ratchadaphiseksomphot Endowment Fund, Chulalongkorn University under Grant number (DNS 63_039_53_002_1). We would like to thank the College of Public Health Science, Chulalongkorn University and all staff members for laboratory assistances and instrument supports. 


\section{ABBREVIATIONS}

WHO: World Health Organization; ICH: International Conference on Harmonisation of Technical Requirements for Registration of Pharmaceuticals for Human Use; TLC: Thin layer chromatography; RP-HPLC: Reversed-phase high-performance liquid chromatography; LOD: Limit of detection; LOQ: Limit of quantitation; $\mathrm{IC}_{50}$ : a halfmaximal inhibitory concentration.

\section{CONFLICTS OF INTEREST}

The authors declare to have no conflicts of interest.

\section{RERFENCES}

1. Yu Y, Li H, Zhang B, Wang J, Shi X, Huang J, et al. Nutritional and functional components of mulberry leaves from different varieties: Evaluation of their potential as food materials. Int J Food Prop 2018; 21: 1495-1507. http://doi.org/10.1080/10942912.2018.1489833.

2. Hu X-Q, Jiang $L$, Zhang J-G, Deng W, Wang H-L, Wei Z-J. Quantitative determination of 1-deoxynojirimycin in mulberry leaves from 132 varieties. Ind Crops Prod 2013; 49: 782-784. http:// doi.org/10.1016/j.indcrop.2013.06.030.

3. Singh R, Bagachi A, Semwal A, Bharadwaj A. Traditional uses, phytochemistry and pharmacology of Morus alba Linn.: A review. J Med Plants Res 2013; 7: 461-469. http://doi.org/10.5897/ JMPR12.1079.

4. Wattanapitayakul SK, Chularojmontri L, Herunsalee A Charuchongkolwongse S, Niumsakul S, Bauer JA. Screening of antioxidants from medicinal plants for cardioprotective effect against doxorubicin toxicity. Basic Clin Pharmacol Toxicol 2005; 96: 80-87. http://doi.org/10.1111/j.1742-7843.2005.pto960112.x.

5. de Oliveira AM, Mesquita MdS, da Silva GC, de Oliveira Lima $\mathrm{E}$, de Medeiros PL, Paiva PMG, et al. Evaluation of toxicity and antimicrobial activity of an ethanolic extract from leaves of Morus alba L. (Moraceae). Evid Based Complement Alternat Med 2015; 2015: 513978. http://doi.org/10.1155/2015/513978.

6. Park JM, Bong HY, Jeong HI, Kim YK, Kim JY, Kwon O. Postprandia hypoglycemic effect of mulberry leaf in Goto-Kakizaki rats and counterpart control Wistar rats. Nutr Res Pract 2009; 3: 272-278. http://doi.org/10.4162/nrp.2009.3.4.272.

7. Mohammadi J, Naik PR. Evaluation of hypoglycemic effect of Morus alba in an animal model. Indian J Pharmacol 2008; 40: 15-18. http://doi.org/10.4103/0253-7613.40483.

8. Hunyadi A, Martins A, Hsieh T-J, Seres A, Zupkó I. Chlorogenic acid and rutin play a major role in the in vivo anti-diabetic activity of Morus alba leaf extract on type II diabetic rats. PloS One 2012; 7: e50619. http://doi.org/10.1371/journal.pone.0050619.

9. Oh K-S, Ryu SY, Lee S, Seo HW, Oh BK, Kim YS, et al. Melaninconcentrating hormone-1 receptor antagonism and anti-obesity effects of ethanolic extract from Morus alba leaves in diet-induced obese mice. J Ethnopharmacol 2009; 122: 216-220. http://doi. org/10.1016/j.jep.2009.01.020.

10. Niidome T, Takahashi K, Goto Y, Goh S, Tanaka N, Kamei K, et al. Mulberry leaf extract prevents amyloid beta-peptide fibril formation and neurotoxicity. Neuroreport 2007; 18: 813-816. http://doi. org/10.1097/WNR.0b013e3280dce5af.
11. Hogade MG, Patil KS, Wadkar GH, Mathapati SS, Dhumal PB Hepatoprotective activity of Morus alba (Linn.) leaves extract against carbon tetrachloride induced hepatotoxicity in rats. Afr J Pharm Pharmacol 2010; 4: 731-734.

12. Lee SH, Choi SY, Kim H, Hwang JS, Lee BG, Gao JJ, et al. Mulberroside $\mathrm{F}$ isolated from the leaves of Morus alba inhibits melanin biosynthesis. Biol Pharm Bull 2002; 25: 1045-1048. http:// doi.org/10.1248/bpb.25.1045.

13. Dat NT, Binh PTX, Quynh LTP, Van Minh C, Huong HT, Lee JJ. Cytotoxic prenylated flavonoids from Morus alba. Fitoterapia 2010; 81: 1224-1227. http://doi.org/10.1016/j.fitote.2010.08.006.

14. Chen C, Mohamad Razali UH, Saikim FH, Mahyudin A, Mohd Noor NQI. Morus alba L. plant: Bioactive compounds and potential as a functional food ingredient. Foods 2021; 10: 689. http://doi. org/10.3390/foods10030689.

15. Naveed M, Hejazi V, Abbas M, Kamboh AA, Khan GJ, Shumzaid M, et al. Chlorogenic acid (CGA): A pharmacological review and call for further research. Biomed Pharmacother 2018; 97: 67-74. http://doi. org/10.1016/j.biopha.2017.10.064.

16. Santana-Gálvez J, Cisneros-Zevallos L, Jacobo-Velázquez DA. Chlorogenic acid: Recent advances on its dual role as a food additive and a nutraceutical against metabolic syndrome. Molecules 2017 22: 358. http://doi.org/10.3390/molecules22030358.

17. World Health Organization. Quality control methods for herbal materials. Geneva: WHO, 2011, p. 9-35.

18. Gul R, Jan SU, Faridullah S, Sherani S, Jahan N. Preliminary phytochemical screening, quantitative analysis of alkaloids, and antioxidant activity of crude plant extracts from Ephedra intermedia indigenous to Balochistan. Sci World J 2017; 2017: 5873648. http:// doi.org/10.1155/2017/5873648

19. Parbuntari H, Prestica Y, Gunawan R, Nurman MN, Adella F. Preliminary phytochemical screening (qualitative analysis) of cacao leaves (Theobroma cacao L.). Eksakta: Berkala IImiah Bidang MIPA 2018; 19: 40-45. http://doi.org/10.24036/eksakta/vol19-iss2/142.

20. The International Conference on Harmonisation of Technical Requirements for Registration of Pharmaceuticals for Human Use. ICH Harmonised Tripartite Guideline, Validation of Analytical Procedures: Text and Methodology Q2 (R1). Geneva: ICH. 2005.

21. Do QD, Angkawijaya AE, Tran-Nguyen PL, Huynh LH, Soetaredjo FE, Ismadji $S$, et al. Effect of extraction solvent on total phenol content, total flavonoid content, and antioxidant activity of Limnophila aromatica. J Food Drug Anal 2014; 22: 296-302. http:// doi.org/doi.org/10.1016/j.jfda.2013.11.001.

22. Klimko M. Micromorphology and anatomy of leaves of Morus alba L.(Moraceae) cultivars from Poland. Steciana 2016; 20: 73-83. http://doi.org/10.12657/steciana.020.009.

23. Wang W, Zu Y, Fu Y, Efferth T. In vitro antioxidant and antimicrobia activity of extracts from Morus alba L. leaves, stems and fruits. Am J Chin Med 2012; 40: 349-356. http://doi.org/10.1142/ s0192415x12500279. 


\section{GRAPHICAL ABSTRACT}

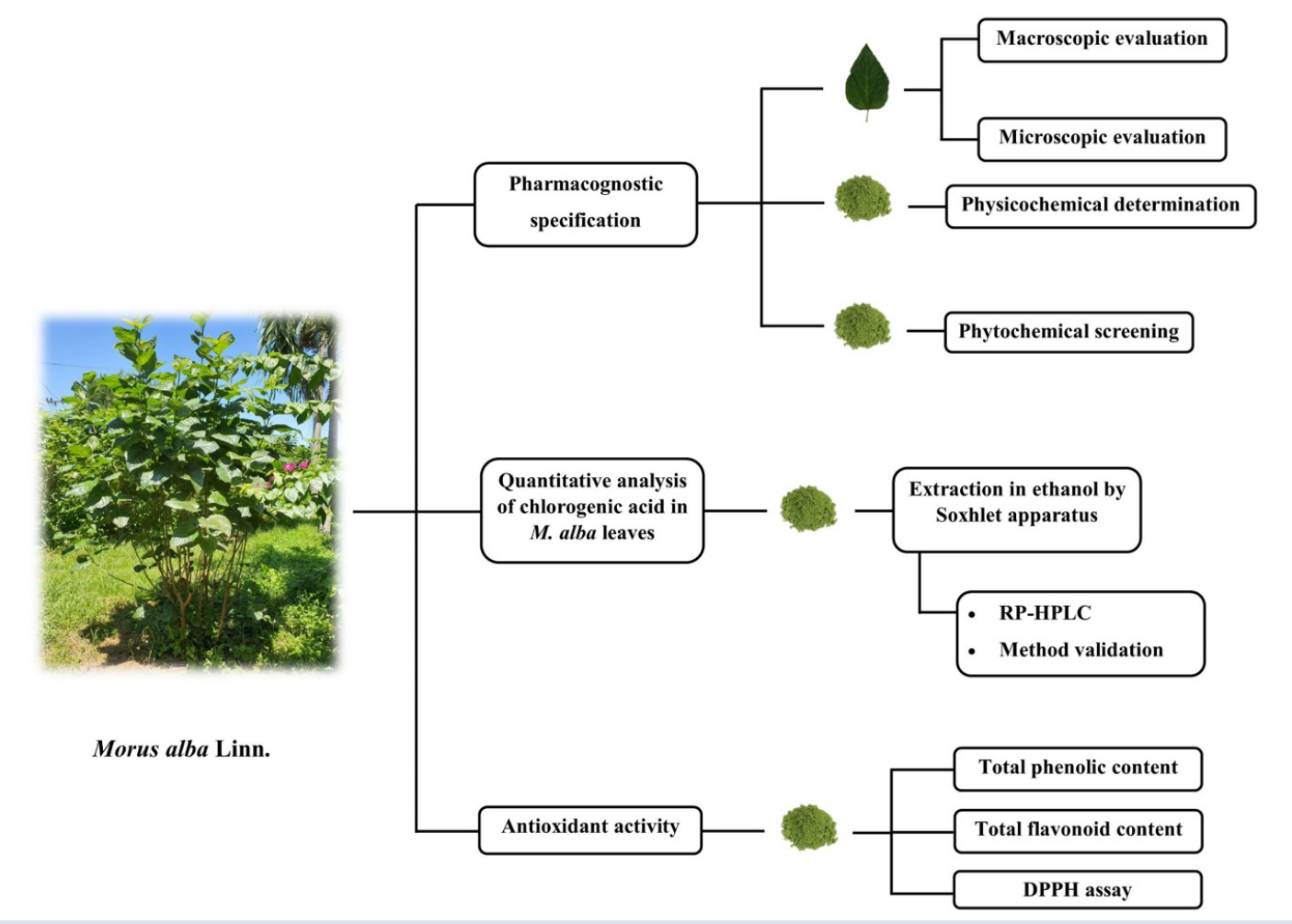

\section{ABOUT AUTHORS}
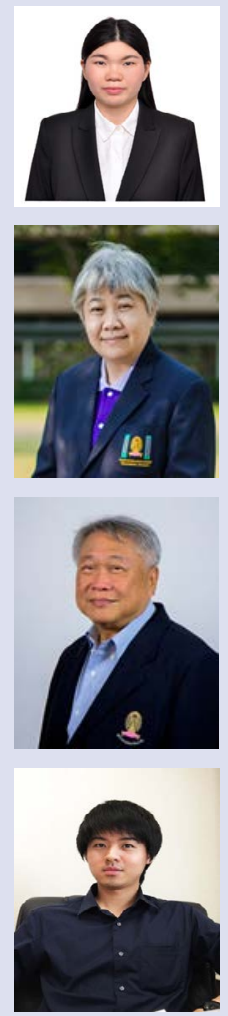

Phimkun Aiyarakanchanakun is an M.Sc. student at College of Public Health Sciences, Chulalongkorn University. Her research work focuses on standardization of plant materials.

Chanida Palanuvej (Ph.D.) is an associate professor at College of Public Health Sciences, Chulalongkorn University. Her research interests focus on standardization and biological evaluations of herbal drugs.

Nijsiri Ruangrungsi (Ph.D.) is an associate professor at College of Public Health Sciences, Chulalongkorn University. His research interests focus on pharmacognosy, plant taxonomy and herbal medicine.

Anuchit Phanumartwiwath (Ph.D.) is a lecturer at College of Public Health Sciences, Chulalongkorn University. His research interests focus on natural product chemistry and protein engineering. 